\title{
YOUTH CORRECTION: READMISSION OF REHABILITATED OFFENDERS TO SOCIETY
}

\author{
SANFORd Batrs*
}

We cannot discuss nowadays correctional or penal methods without soon coming to a realization that the method and manner of release into the community of offenders committed to institutions, are second in importance only to the quantity and quality of after-care-supervision.

Former Attorney General Homer S. Cummings, in a nation-wide radio address, ${ }^{1}$ shared with the public an idea that had been growing upon him. The title of his talk was, "They All Come Out" and so they do. A few of them feet first but most of them prepared for better or worse to resume life in society. It's a shortsighted view of the prison problem which considers only that fatal day in a man's life when he is locked behind the prison bars. An even more fatal day for the public than for him is that occasion on which the prison door swings the other way and he emerges into the sunlight of reality. Any correctional system which protects the public only while the man is safely immured in one of our many Bastille-like prisons, is not rendering to the public the full protection to which it is entitled.

Parole is the name we give to that form of conditional discharge from prison which presupposes an ensuing period of control and supervised residence in the community. It is the acid test of the success of our penal system. Whether a man has been improved or degraded by his prison experience, is not likely to be determined until he is tried out in the community. That there are ways of improving him, is beyond doubt. His body can be cured of disease; his mind may be cleansed of its delusions; he may be taught the rudiments of a trade and even more important, he may acquire the habit of steady and purposeful work. He may be set the example of diligence, honesty and fair dealing among men and he may be brought occasionally in touch with some of the higher and nobler things of life through the chaplain, the school and the library, and he may learn something of the importance of knowing how to live with his fellowmen in a democracy. On the other hand, his health may be endangered and his energy depleted. He may, without proper guidance or

- LL.B., I906, LL.D., 1937, Northeastern University. Member of the Massachusetts Bar. Commissioner of Parole, State of New York, since 1940. Director, United States Bureau of Prisons, 1930-1937; Executive Director, Boys Clubs of America, 1937-1940; member of faculty, New York School of Social Work, since 1937; instructor, Division of Handicapped, Teachers College, Columbia University, since 1938. Officer or director of numerous organizations in the field of social work. Author of PRISONS AND Beyond (1938). Contributor to periodicals.

${ }^{2}$ This address is reprinted in 83 CoNG. REc. $2{ }_{34}$ (r938). 
discipline, sink to the level of those about him who are more degraded than himself and he may imitate the slothfulness, conniving, cruelty and pettiness of those around him or even above him.

Parole then, to fulfil its role as the proving ground of a good penal system, must inevitably be preceded by a sincere, intelligent and courageous attempt to break down some of the age-long traditions of the prison and substitute therefor a genuine att tempt at rehabilitation. The difficulty of this process is recognized by all realistically minded people. Helpful and intelligent efforts have been made to elevate the correctional effort.

The now historic findings of Dr. and Mrs. Glueck ${ }^{2}$ have been generally hailed as demonstrating a considerable lack of success for the reformatory method. Sixty per cent of the graduates of a reformatory in an Eastern State slipped back into crime within five years from the day of their release. Another $20 \%$ had some minor brush with the law and only $20 \%$ could be placed by these two conscientious investigators into the "driven snow" classification. On second thought, however, this finding is not as discouraging as it might seem. From the Gluecks' own figures only a handful of the 500 inmates whose cases they examined, could really be called "pure" when they came to the reformatory. Their investigations were based upon the situation prevailing during World War No. I and this and other factors have probably put a more unfavorable aspect upon their conclusions than would now be reflected in a current study of the same institution.

The fact to be here noted is that these and other studies proceed upon the important assumption that treatment on parole is an integrated part of the correctional process.

In discussing the prospect of improved handling of juvenile offenders under the Youth Correction Authority plan or any other plan which may be proposed, the method of release into the community must have prominent place. In fact, it was not long after Attorney General Cummings decided that they "must all come out" that he sponsored a million dollar WPA inquiry into the whole subject of release procedures, and this monumental five-volume work, ${ }^{3}$ completed under the leadership of Dean Wayne L. Morse, now reposes in the archives of Washington. An equally significant although less ponderous inquiry into the relationship of parole to institutional treatment, is contained in a pamphlet entitled, "Institutional Treatment of Delinquent Boys," published in 1936. This is Part 2 of a study of $75 \mathrm{I}$ boys and comprises Publication No. 230 of the Children's Bureau of the United States Department of Labor. These 75I boys had been committed to five juvenile correctional schools. Two of these schools, in the judgment of this writer, were excellently managed institutions. It is difficult to see how they could have been any better. I for one do not know where I should go to get men to administer boys' institutions with more skill and idealism than Calvin Derrick and Kenyon Scudder. On the other hand,

\footnotetext{
2 Sheldon \& E. T. Glueck, 500 Crminal Careers (1930).

'Attorney General's Survey of Release Procedures (1939). Volume 2 deals specifically with the parole problem.
} 
the other three schools were not so good. One of the disturbing revelations from this Children's Bureau study was that the success of these boys on parole did not strikingly vary as between the good schools and the bad. The final evaluation of the adjustment which these boys made to the general requirements of community life, resulted in a rating of generally successful $32 \%$, doubtful $33 \%$, unsuccessful $35 \%$.

It appears from the report, however, that in many cases these parole failures did not occur immediately but only after a considerable residence back in the neighborhood where these delinquents were originally produced. This, of course, leaves it open to the defenders of the juvenile training schools to say that when these boys left their portals they meant to do well, they had been physically, mentally and morally rehabilitated, but they could not withstand the temptations of free life on the outside. They may be partly right but this study should convince us of two important facts. The first is that training in an institution should not be aimed at producing good inmates but rather at developing good citizens. Second, that no parole system can get the best results unless it recognizes the essential part which social agencies and community influence play in such processes.

The commonly voiced explanation of the failure of some of our juvenile courts is that they did not get the full cooperation of the social agencies and no procedure for the control or guidance of prisoners released from our institutions can wholly succeed except through the understanding and tolerant participation by the community. It will not be enough, therefore, for the Youth Correction Authority to set up an ideal system of releases based upon indeterminate sentences. It will not be enough to hire qualified parole officers or even to appoint first friends or sponsors for the paroled youth. A more comprehensive scheme of community effort must be contrived if the readmission of rehabilitated offenders to society is to be accomplished with safety. 